\title{
PENENTUAN UMUR SIMPAN SIRUP KRANJI (Dialium indum L.) MENGGUNAKAN METODE ACCELERATED SHELF-LIFE TESTING (ASLT) SUHU
}

\author{
Determination Of Keranji (Dialium Indum L.) Syrup Shelf-Life Usingaccelerated Shelf-Life \\ Testing(Aslt) Of Temperature Method \\ Encik Eko Rifkowaty ${ }^{1}$ Khairul Muttaqin ${ }^{2)}$ \\ ${ }^{1}$ Fakultas Teknologi Pertanian, Politeknik Negeri Ketapang \\ email: encikviollette@yahoo.com \\ ${ }^{2}$ Fakultas Teknik Pertambangan, Politeknik Negeri Ketapang
}

\begin{abstract}
Keranji syrup is one of diversify products of keranji. This research was to determine the shelf life of keranji syrup using ASLT (Accelerated Shelf Life Testing) with the Arrhenius equation based on the change in quality during storage. The advantage of this research is to give information about expired date of the product. In this research, keranji syrup stored at $30^{\circ} \mathrm{C}, 40^{\circ} \mathrm{C}$ and $50^{\circ} \mathrm{C}$ for 4 weeks. The parameters used to analyze were vitamin $\mathrm{C}, \mathrm{pH}$, total dissolved solids, total yeast and organoleptic tests. The results showed that the shelf life determination are based on the total yeast because it has the smallest activation energy, ie $536.19 \mathrm{cal} / \mathrm{mol}$. Shelf life of keranji syrup at room temperature storage $\left(30^{\circ} \mathrm{C}\right)$ was 20 days, and organoleptic score (accepbility of panelis) $61 \%$.
\end{abstract}

Keywords : keranji syrup, shelf life, ASLT, arrhenius

\begin{abstract}
ABSTRAK
Keranji merupakan buah musiman yang banyak terdapat pada bulan Januari hingga April. Saat terjadi lonjakan panen, buah keranji melimpah di pasaran. Diversifikasi produk pangan berbahan baku keranji dapat dilakukan seperti pembuatan sirup, sehingga dapat menambah nilai ekonomis keranji. Indonesia yang beriklim tropis menjadikan sirup mudah diterima ditengah masyarakat. Pengetahuan mengenai umur simpan sirup keranji perlu dilakukan sebagai upaya keamanan pangan dan memberikan informasi kepada masyarakat. Pendugaan umur simpan sirup keranji dilakukan dengan metode ASLT (Accelerated Shelf Life Testing) suhu menggunakan pendekatan Arrhenius. Pengamatan terhadap perubahan mutu dilakukan selama periode waktu tertentu. Parameter yang diamati antara lain vitamin $\mathrm{C}, \mathrm{pH}$, padatan terlarut, dan total kapang. Plot perubahan mutu versus lama penyimpanan didapatkan persamaan linier. Plot eksponensial nilai slope $(\ln \mathrm{k})$ versus suhu $\left(1 / \mathrm{T}\left({ }^{\circ} \mathrm{K}\right)\right)$ didapatkan persamaan Arrhenius y $=\mathrm{a}+$ bx atau $\ln \mathrm{k}=\ln \mathrm{ko}-\mathrm{Ea} / \mathrm{RT}$. Pendugaan umur simpan ditentukan berdasarkan parameter yang memiliki nilai energi aktivasi terkecil. Energi aktivasi vitamin $\mathrm{C}, \mathrm{pH}$, total padatan terlarut, dan total kapang berturut-turut $8215,20,1332,70,11215,03,536,19 \mathrm{kal} / \mathrm{mol}$, sehingga pendugaan umur simpan ditentukan berdasarkan parameter total kapang. Umur simpan sirup keranji pada suhu $30^{\circ} \mathrm{C}$ yaitu \pm 20 hari, dengan skor penerimaan konsumen $61 \%$.
\end{abstract}

Kata kunci: sirup keranji, ASLT suhu, umur simpan

\section{PENDAHULUAN}

Buah kranji disebut juga Luk Yee atau Yee (Thailand), dan kranji (Malaysia dan Indonesia).Buah kranji (Dialium indum L.) berbentuk seperti kelereng, dengan kulityang agak keras berwana hitam, daging buah berwarna orange ataupun hitam, yang memiliki rasa yang asam manis dan biji yang 
keras berwarna coklat muda (Biojana, 2012). Buah keranji merupakan buah musiman, di Indonesia pohon ini berbunga dari Nopember-Desember dan berbuah hingga siap panen antara bulan Januari-April setiap 1 tahun sekali (Anonim, 2013).

Pengolahan buah menjadi sirup merupakan tindakan untuk menambah nilai ekonomis serta memperpanjang umur simpan produk (Biojana, 2012). Demikian hal nya pada buah kranji.Sirup kranji merupakan produk baru. Indonesia yang beriklim tropis, sehingga minuman yang menyegarkan seperti sirup mudah diterima ditengah masyarakat.

Berdasarkan SNI 01-35441994beberapa parameter yang digunakan sebagai atribut mutu sirup beberapa diantaranya; uji cemaran mikrobia (total kapang), uji kimia (total gula), $\mathrm{pH}$, serta uji organoleptik terhadap aroma, rasa, warna.

Kerusakan yang biasanya terjadi pada sirup buah maupun minuman sari buah yaitu penurunan kadar vitamin $\mathrm{C}$, kerusakan akibat mikroorganisme yang akan mempengaruhi atribut mutu fisik maupun kimia lainnya. Penelitian Martono, Sari, Hidarto (2014)penurunan kandungan vitamin $\mathrm{C}$ pada sirup yang disimpan pada berbagai suhu dapat digunakan untuk menduga umur simpan pada produk sirup tersebut. Menurut Buckle et al (1985) khamir/kapang merupakan organisme yang merusak produk pangan yang berkadar gula tinggi seperti sirup.

Perubahan pada atribut mutu tersebut dapat digunakan untuk memprediksi umur simpan simpan sirup kranji. Metode pendugaan umur simpan dapat dilakukan dengan metode AcceleratedShelf-Life Testing (ASLT).Metode ASLT dilakukan dengan menggunakan suatu kondisi yang dapat mempercepat (accelareted) proses penurunan mutu produk pangan, seperti suhu, kelembaban, atmosfer gas, dan cahaya (Arpah, 2003). Penentuan umur simpan berdasarkan akselerasi suhu dilakukan untuk mengetahui perubahan mutu selama penyimpanan yang dipengaruhi oleh kondisi suhu penyimpanan. Secara umum, laju reaksi kimia akan semakin cepat pada suhu yang lebih tinggi yang berarti penurunan mutu produk akan semakin cepat terjadi.

\section{METODE PENELITIAN}

\section{Tempat dan waktu penelitian}

Penelitian ini dilakukan di laboratorium Teknologi Pertanian, Politeknik Negeri Ketapang pada bulan April hingga Agustus.

\section{Bahan}

Bahan yang digunakan dalam pembuatan sirup adalah buah kranjiyang telah dikupas dan dipisahkan dari bijinya. Bahan kimia yang digunakan untuk menunjang analisa vitamin $\mathrm{C}$ dan total kapang.

\section{Alat}

Alat-alat yang digunakan dalam pembuatan sirup antara lain;timbangan, pengaduk, panci, kompor gas, botol dan tutup yang sudah disetrilkan, kain saring, baskom, corong,dan pompa vakum.

Alat yang digunakan dalam proses analisa antara lain $\mathrm{pH}$ meter, incubator, refractometer dan alat-alat analisa lainnya.

Produk sirup kranji yang baru diproduksi disimpan pada tiga kondisi suhu, yaitu $30^{\circ} \mathrm{C}, 40^{\circ} \mathrm{C}$, dan $50^{\circ} \mathrm{C}$. Penentuan karakteristik mutu sirup diamati secara berkala mulai hari ke-0 hingga hari akhir pengamatan.

Parameter perubahan mutu yang diamati meliputi vitamin $\mathrm{C}$ metode titrasi iodin, $\mathrm{pH}$, total padatan terlarut, dan total kapang, serta uji organoleptik yang meliputi rasa, bau, dan warna untuk mengetahui skor penerimaan konsumen terhadap sirup kranji selama penyimpanan.

Perubahan mutu sampel diamati tiap interval waktu tertentu pada berbagai suhu $\left(30,40,50^{\circ} \mathrm{C}\right)$. Tiap pengamatan dilakukan duplo. Kadar vitamin $\mathrm{C}$ diamati hingga mendekati $0 \%$, sedangkan akhir pengamatan ALT, $\mathrm{pH}$ dan total padatan terlarut jika 
perhitungan total kapang mencapai $5 \times 10$ koloni/ml.

\section{Analisa Data}

\section{Pengujian perubahan mutu secara kimia dan mikroorganime}

Data perubahan mutu sampel selama penyimpanan digunakan untuk menentukan umur simpan.

\section{Plot kurva perubahan mutu (A) versus waktu (t)}

Pada tahap ini data perubahan mutu produk diplotkan ke dalam grafikperubahan mutu (A) (sumbu y) versus waktu (t) (sumbu $\mathrm{x}$ ), dan grafik $\ln (\mathrm{A})$ versus (t), sehingga akandidapatkan 3 (tiga) persamaan linier $\mathrm{y}=$ $\mathrm{a}+\mathrm{bx}$ pada tiap suhu penyimpanan $(30,40$, dan $50^{\circ} \mathrm{C}$ ), dimana nilai slope $=\mathrm{b}=\mathrm{k}$.

\section{Penentuan ordo reaksi}

Ordo reaksi ditentukan berdasarkan nilai koefisien determinasi $\left(\mathrm{R}^{2}\right)$.Orde reaksi dengan nilai $\mathrm{R}^{2}$ yang lebih besar merupakan orde reaksi yang digunakan oleh parameter tersebut.

Plot kurva pra-eksponensial k (ln k) versus suhu $\left(1 / \mathrm{T}_{\text {dalam }}{ }^{\mathrm{o}} \mathrm{K}\right)$

Persamaan Arrhenius didapatkan dari plot pra-eksponensial (ln k) (sumbu y) versus invers suhu (1/T dalam ${ }^{\circ} \mathrm{K}$ ) (sumbu $\mathrm{x}$ ) akan dihasilkan persamaan linier $\mathrm{y}=\mathrm{a}+\mathrm{bx}$ atau $\ln \mathrm{k}$ $=\ln \mathrm{ko}-\mathrm{Ea} / \mathrm{RT}$.

\section{Penentuan Energi Aktivasi}

Energi aktivasi (kal/mol) dihasilkan dari nilai slope $=b$ pada persamaan Arrhenius dikali dengan $\mathrm{R}$ (konstanta 1,987 $\left.\mathrm{kal} / \mathrm{mol}^{\mathrm{o}} \mathrm{K}\right)$.

\section{Prediksi umur simpan}

Nilai laju reaksi k pada suhu tertentu ditentukan dengan memasukkan nilai suhu 1/T $\left({ }^{\circ} \mathrm{K}\right)$ kedalam persamaan Arrhenius. Prediksi umur simpan didapatkan dari selisih perubahan mutu awal dan akhir penyimpanan dibagi nilai $\mathrm{k}$.

$t=\frac{A-A o}{k} \quad$ (ordo nol)

$$
t=\frac{\ln A-\ln A o}{k \quad \text { (ordo satu) }}
$$

$\mathrm{A}=$ parameter mutu akhir penyimpanan

Ao = parameter mutu awal penyimpanan

$\mathrm{k}$ = laju reaksi pada suhu tertentu

\section{HASIL DAN PEMBAHASAN}

\section{Uji Organoleptik}

Berdasarkan uji organoleptik penerimaan konsumen terhadap sirup kranji pada minggu ke-3 setelah penyimpanan pada berbagai suhu mencapai kisaran $55-61 \%$. Titik kritis sirup kranji ditentukan ketika skor penolakan konsumen mencapai $50 \%$.

Menurut Cardelliet al., (2001); Hough, Garitta, and Go'mez (2006), penentuan umur simpan sama dengan waktu saat $50 \%$ atau lebih konsumen menolak produk. Apabila penurunan mutu belum mencapai 50\%, maka akan terjadi perbedaan yang kecil, sehingga sulit menentukan ordo dari suatu reaksi (Arpah, 2003). Skor penerimaan konsumen terhadap sirup ditentukan berdasarkan atribut warna, rasa dan aroma.

Skor penerimaan mengalami penurunan selama penyimpanan. Hal ini dikarenakan warna sirup selama penyimpanan cenderung berubah menjadi lebih gelap yang disebabkan karena adanya reaksi kimia seperti reaksi karamelisasi.

Uji kesukaan panelis terhadap rasa menyatakan bahwa sirup keranji yang disimpan pada suhu $30^{\circ} \mathrm{C}$ dan $40^{\circ} \mathrm{C}$ lebih disukai dibandingkan sirup keranji yang disimpan pada suhu $50^{\circ} \mathrm{C}$. Hal ini disebabkan rasa asam pada sirup keranji hilang akibat suhu penyimpanan $50^{\circ} \mathrm{C}$. Kondisi ini mempengaruhi persepsi konsumen atau panelis terhadap penerimaan produk. Pendapat ini sesuai dengan Mukaromah, Susetyorini, Aminah, (2010) zat asam organik yang terdapat pada rosella dapat hilang akibat dari pemanasan. 
Tabel 1. Organoleptik sirup kranji selama uji penyimpanan

\begin{tabular}{|c|c|c|c|c|c|c|}
\hline \multirow{2}{*}{ Ha-ri ke- } & \multicolumn{3}{|c|}{ Hasil uji organoleptik } & \multirow{2}{*}{$\begin{array}{l}\% \text { keselu- } \\
\text { ruhan }\end{array}$} & \multirow{2}{*}{$\begin{array}{l}\text { Skor } \\
\text { peneri- } \\
\text { maan }\end{array}$} & \multirow{2}{*}{$\begin{array}{c}\text { Skor } \\
\text { penolak-an }\end{array}$} \\
\hline & Warna & Aroma & Rasa & & & \\
\hline 0 & 0,93 & 0,97 & 0,97 & 2,87 & 96,67 & 3,33 \\
\hline 21 & 0,53 & 0,70 & 0,57 & 1,80 & 60,00 & 40,00 \\
\hline
\end{tabular}

Aroma sirup yang disimpan selama \pm 3 minggu masih memiliki aroma khas sirup keranji. Namun sirup keranji yang disimpan pada suhu $30^{\circ} \mathrm{C}$ aroma khas keranji sedikit memudar. Hal ini disebabkan karena tumbuhnya kapang di dalam bahan pangan dapat mengubah komposisi bahan pangan, menghidrolisa pati dan selulosa atau menyebabkan fermentasi gula, sehingga dapat mempengaruhi aroma produk (Muchtadi, 2010).
Perubahan mutu yang diukur pada sirup kranji meliputi; vitamin $\mathrm{C}, \mathrm{pH}$, total padatan terlarut, dan total kapang.Secara keseluruhan, laju reaksi kerusakan dapat ditentukan berdasarkan ordo reaksi. Ordo reaksi ditentukan berdasarkan akuransi determinasi $\left(\mathrm{R}^{2}\right)$ dari reaksi perubahan mutu selama penyimpanan (Fennema, 1996; Anonymous, 2008; Anonymous, 2010 ${ }^{\mathrm{b}}$ ).

Tabel 2. Karakteristik nilai mutu awal dan nilai mutu akhir selama penyimpanan

\begin{tabular}{ccccc}
\hline \multirow{2}{*}{ Paramater } & \multicolumn{4}{c}{ Sirup Kranji } \\
\cline { 2 - 5 } & $\begin{array}{c}\text { Awal } \\
\text { Penyimpanan }\end{array}$ & \multicolumn{3}{c}{$\begin{array}{c}\text { Akhir } \\
\text { Penyimpanan }\end{array}$} \\
\cline { 2 - 5 } & & $30^{\circ} \mathrm{C}$ & $40^{\circ} \mathrm{C}$ & $50^{\circ} \mathrm{C}$ \\
\hline Vitamin C (\%) & 2,70 & 1,41 & 0,79 & 0,25 \\
pH & 5,46 & 4,19 & 4,36 & 4,54 \\
Total Padatan Terlarut (brix) & 60 & 32 & 48 & 52 \\
Total Kapang (koloni) & 0 & $>50$ & 23 & 14 \\
\hline
\end{tabular}

Vitamin C

Tabel 3. Persamaan regresi linier parameter vitamin c orde nol dan orde satu

\begin{tabular}{ccccc}
\hline $\begin{array}{c}\text { Suhu T } \\
\left({ }^{\circ} \mathrm{C} /{ }^{\circ} \mathrm{K}\right)\end{array}$ & \multicolumn{2}{c}{ Orde Nol } & \multicolumn{3}{c}{ Orde Satu } \\
\cline { 2 - 5 } & Persamaan Linier & $\mathrm{R}^{2}$ & Persamaan Linier & $\mathrm{R}^{2}$ \\
\hline $30(303)$ & $\mathrm{y}=-0,0332 \mathrm{x}+2,3592$ & 0,8641 & $\mathrm{y}=-0,0357 \mathrm{x}+1,1513$ & 0,7321 \\
& & & & \\
$40(313)$ & $\mathrm{y}=-0,0608 \mathrm{x}+2,6422$ & 0,9398 & $\mathrm{y}=-0,0623 \mathrm{x}+1,2863$ & 0,9370 \\
& & & & \\
$50(323)$ & $\mathrm{y}=-0,0770 \mathrm{x}+2,3591$ & 0,8717 & $\mathrm{y}=-0,0841 \mathrm{x}+1,1617$ & 0,7380 \\
\hline
\end{tabular}




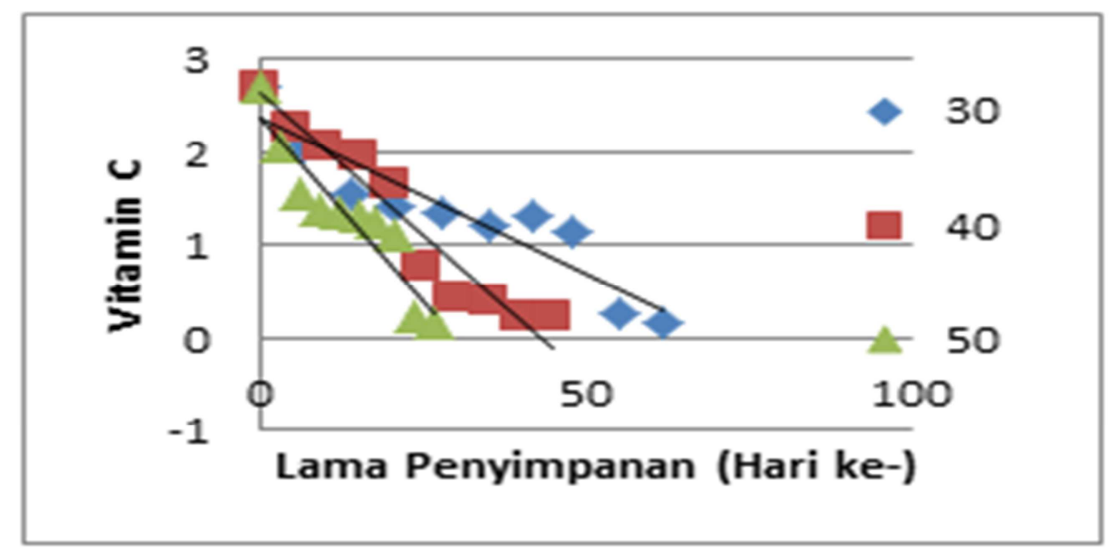

Gambar1. Grafik vitamin C sirup kranji selama penyimpanan pada berbagai suhu

Pengamatan mutu sirup kranji berdasarkan parameter vitamin $\mathrm{C}$ berakhir jika kadar vitamin $\mathrm{C}$ mendekati angka nol atau sama dengan nol. Pada suhu $50^{\circ} \mathrm{C}$ mengalami penurunan dengan persentase terbesar hal ini dikarenakan pengaruh suhu tinggi dapat mempercepat reaksi kerusakan. Pengaruh suhu terhadap laju reaksi mengikuti hukum arhenius. Persamaan Arrhenius menunjukkan ketergantungan laju reaksi kerusakan terhadap suhu. Peningkatan suhu akan meningkatkan laju reaksi dalam jumlah yang besar, dimana peningkatan suhu akan mempengaruhi energi aktivasi (Benson, 1952).

Pemilihan orde reaksi vitamin $\mathrm{C}$ dapat dilihat pada Tabel 3. Dari Tabel 3 dapat diketahui bahwa koefisien korelasi orde nol lebih besar daripada koefisien korelasi orde satu $\left(\mathrm{R}^{2}\right.$ orde nol $>\mathrm{R}^{2}$ ordesatu), maka laju penurunan vitamin $\mathrm{C}$ mengikuti reaksi orde nol.

Dari Gambar 1 dapat diketahui persamaan linier pada masing-masing suhu, sehingga nilai slope dari masing-masing persamaan tersebut dapat digunakan untuk menentukan nilai ln k. Grafik ln k (sumbu y) versus $1 / T$ (sumbu $\mathrm{x}$ ) akan menghasilkan persamanaan linear seperti Gambar 2.

Gambar 2 menunjukan nilai persamaan Arrhenius $\quad \mathrm{y}=-4134,5 \mathrm{x}+10,295$ dari persamaan tersebut dapat dihitung nilai energi aktivasi (Ea). Energi aktivasi didapatkan dari $\mathrm{R}$ nilai konstanta $(1,987$ $\mathrm{kal} / \mathrm{mol}^{\circ} \mathrm{K}$ ) dikalikan dengan nilai slope $=\mathrm{b}$ yaitu 4134,5 sehingga diperoleh $\mathrm{Ea}=8215,2515 \mathrm{kal} / \mathrm{mol}$.

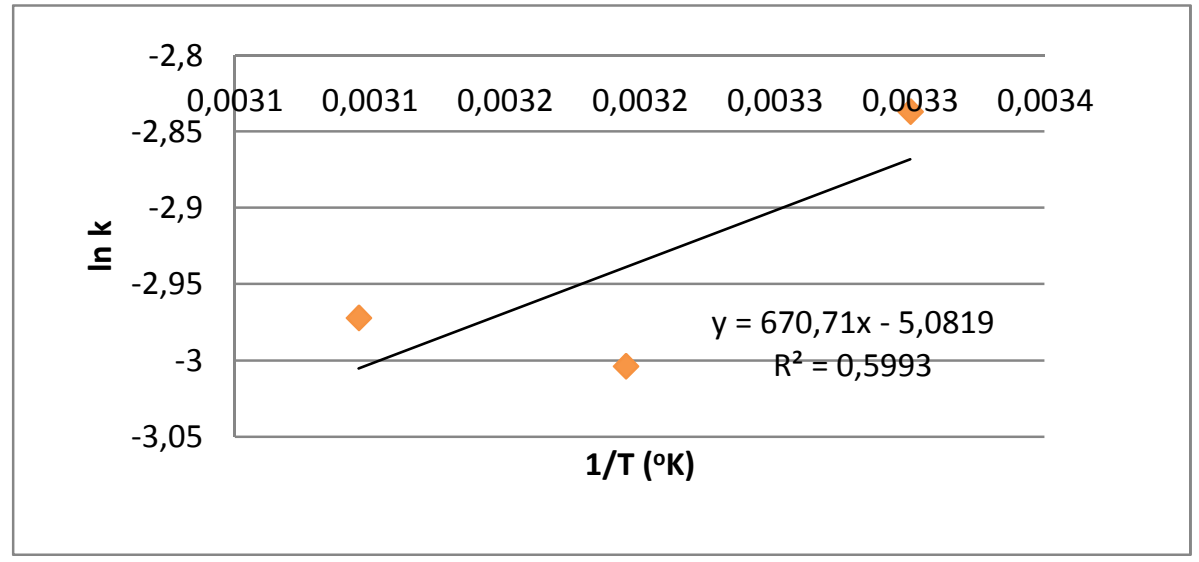

Gambar 2. Grafik Ln k versus suhu $(1 / \mathrm{T})\left({ }^{0} \mathrm{~K}\right)$ parameter Vitamin C 


\section{Analisa total kapang}

Tabel 4. Persamaan regresi linier parameter total kapang ordo nol dan ordo satu

\begin{tabular}{ccccc}
\hline \multirow{2}{*}{$\begin{array}{c}\text { Suhu } \\
\left({ }^{\circ} \mathrm{C} /{ }^{\circ} \mathrm{K}\right)\end{array}$} & \multicolumn{2}{c}{ Ordo Nol } & \multicolumn{2}{c}{ Ordo Satu } \\
\cline { 2 - 5 } & Persamaan Linier & $\mathrm{R}^{2}$ & Persamaan Linier & $\mathrm{R}^{2}$ \\
\hline $30(303)$ & $\mathrm{y}=2,3143 \mathrm{x}-3,3$ & 0,9468 & $\mathrm{y}=1,4107 \mathrm{e}^{0,1815 \mathrm{x}}$ & 0,9998 \\
& & & & \\
$40(313)$ & $\mathrm{y}=1,8057 \mathrm{x}-7,9048$ & 0,8345 & $\mathrm{y}=0,9798 \mathrm{e}^{0,1581 \mathrm{x}}$ & 0,9632 \\
& & & & \\
$50(323)$ & $\mathrm{y}=0,6547 \mathrm{x}-2,3468$ & 0,8995 & $\mathrm{y}=5,1261 \mathrm{e}^{0,1082 \mathrm{x}}$ & 0,8951 \\
& & & & \\
\hline
\end{tabular}

Total kapang merupakan analisa yang digunakan untuk menghitung jumlah kapang yang tumbuh pada sirup keranji dengan menggunakan media PCA (potato destoner agar). Berdasarkan hasil penelitian, suhu mempengaruhi pertumbuhan kapang. Sirup yang disimpan pada suhu $30^{\circ} \mathrm{C}$, peningkatan total kapang semakin cepat. Menurut Winarno (1994), faktor-faktor intrinsik untuk pertumbuhan kapang adalah suhu optimum $25-30^{\circ} \mathrm{C}$ dengan $\mathrm{pH}$ optimum antara $4,0-$ 4,5 yang bisa menyebabkan kerusakan pada bahan seperti pada sirup.

Berdasarkan data hasil analisa total kapang dapat dibuat grafik persamaan linier total kapang versus lama penyimpanan pada masing-masing suhu seperti pada Gambar 3. Pada Tabel 4 diketahui pemilihan ordo reaksi parameter total kapang mengikuti ordo satu

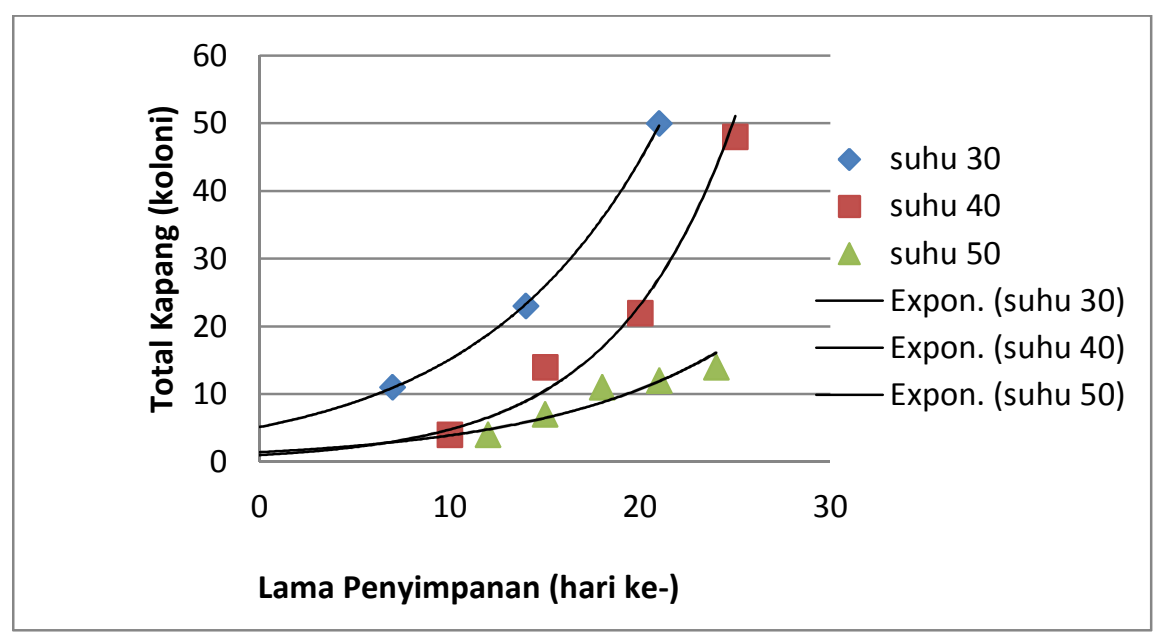

Gambar 3. Grafik persamaan linier total kapang selama penyimpanan pada berbagai suhu 


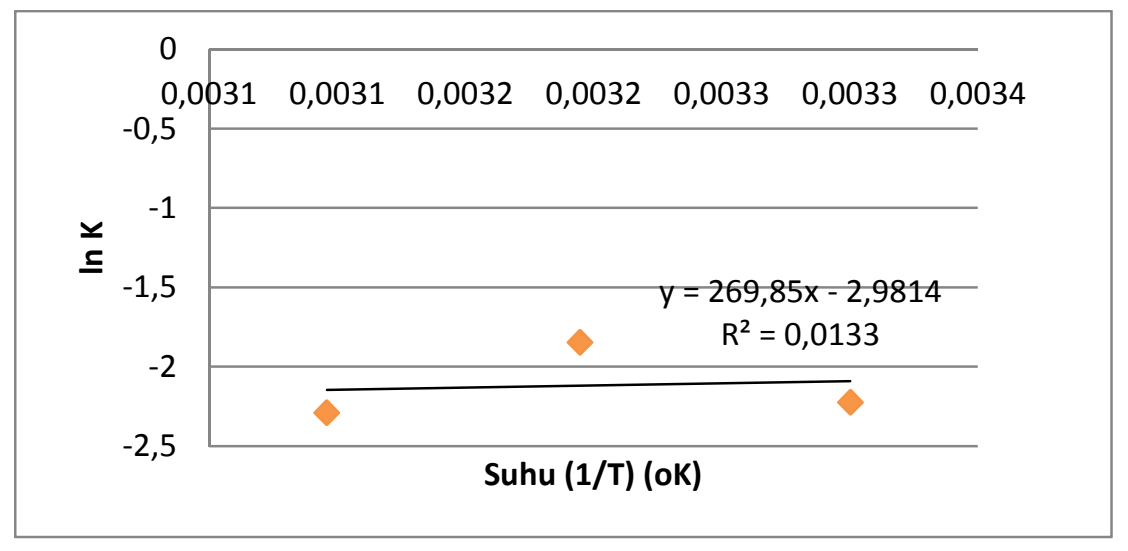

Gambar 4. Grafik Persamaan Arrhenius ln k versus suhu $(1 / \mathrm{t})\left({ }^{0} \mathrm{~K}\right)$ parameter total kapang

Dari grafik dapat diketahui nilai slope masing-masing suhu untuk menentukan nilai $\ln \mathrm{k}$, sehingga dapat dibuat grafik $\ln \mathrm{k}$ versus suhu $(1 / t)\left({ }^{0} \mathrm{~K}\right)$ seperti pada Gambar 4.

Dari gambar 4 didapatkan persamaan y $=269,85 \mathrm{x}-2,9814$, sehingga diperoleh nilai energi aktivasi. Energi aktivasi dihitung dari perkalian antara nilai kemiringan kurva (slope) dengan R. Nilai kemiringan kurva dari persamaan garis ini sebesar 269,85 merupakan nilai $\mathrm{E} / \mathrm{R}$ dari persamaan Arrhenius sedangkan R (konstanta gas) sebesar $1,987 \mathrm{kal} / \mathrm{mol}^{\circ} \mathrm{K}$, sehingga $\mathrm{Ea}=$ $536,192 \mathrm{kal} / \mathrm{mol}$.

\section{Analisa pH}

$\mathrm{pH}$ merupakan salah satu faktor pengendali utama pertumbuhan mikroba pada bahan pangan. Pada umumnya nilai $\mathrm{pH}$ pada bahan pangan berkisar antara 3-8 (supriadi dkk., 1999). pH pada sirup kranji dapat dipengaruhi oleh kandungan vitamin $\mathrm{C}$ maupun aktivitas mikroorganisme seperti kapang. Berdasarkan hasil penelitian diketahui bahwa terjadi penurunan nilai $\mathrm{pH}$ selama penyimpanan. Hal ini kemungkinan diakibatkan oleh aktivitas kapang yang dapat mengeluarkan enzim sehingga dapat mempengaruhi $\mathrm{pH}$ pada sirup.

Penurunan nilai $\mathrm{pH}$ sirup pada penyimpanan suhu $30^{\circ} \mathrm{C}$ lebih besar dikarenakan aktifitas kapang meningkat pada suhu optimum $25-30^{\circ} \mathrm{C}$, sehingga mengakibatkan penurunan nilai $\mathrm{pH}$ (asam) pada sirup.

Tabel 5 dapat diketahui bahwa koefisien korelasi ordo nol lebih besar daripada koefisien korelasi ordo satu $\left(\mathrm{R}^{2}\right.$ ordo nol $>\mathrm{R}^{2}$ ordo satu), maka laju penurunan $\mathrm{pH}$ mengikuti reaksi ordo nol.

Tabel 5. Persamaan regresi linier parameter $\mathrm{pH}$ ordo nol dan ordo satu

\begin{tabular}{|c|l|c|c|c|}
\hline $\begin{array}{c}\text { Suhu T } \\
\left({ }^{\circ} \mathrm{C} /{ }^{\circ} \mathrm{K}\right)\end{array}$ & \multicolumn{2}{|c|}{ Ordo Nol } & \multicolumn{2}{c|}{ Ordo Satu } \\
\cline { 2 - 5 } & Persamaan Linier & $\mathrm{R}^{2}$ & Persamaan Linier & $\mathrm{R}^{2}$ \\
\hline $30(303)$ & $\mathrm{y}=-0,0586 \mathrm{x}+5,61$ & 0,8718 & $\mathrm{y}=-0,0121 \mathrm{x}+1,7309$ & 0,8515 \\
\hline $40(313)$ & $\mathrm{y}=-0,0496 \mathrm{x}+5,62$ & 0,9299 & $\mathrm{y}=-0,0101 \mathrm{x}+1,7315$ & 0,9249 \\
\hline $50(323)$ & $\mathrm{y}=-0,0512 \mathrm{x}+5,6489$ & 0,7795 & $\mathrm{y}=-0,0103 \mathrm{x}+1,7362$ & 0,7838 \\
\hline
\end{tabular}




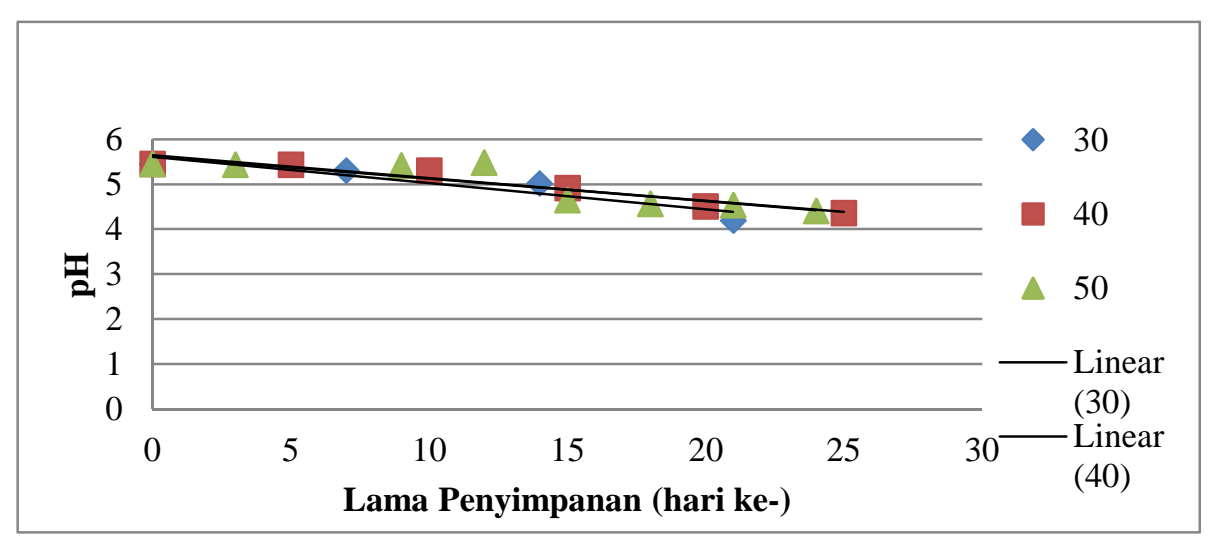

Gambar5. Grafik pH sirup kranji selama penyimpanan pada berbagai suhu

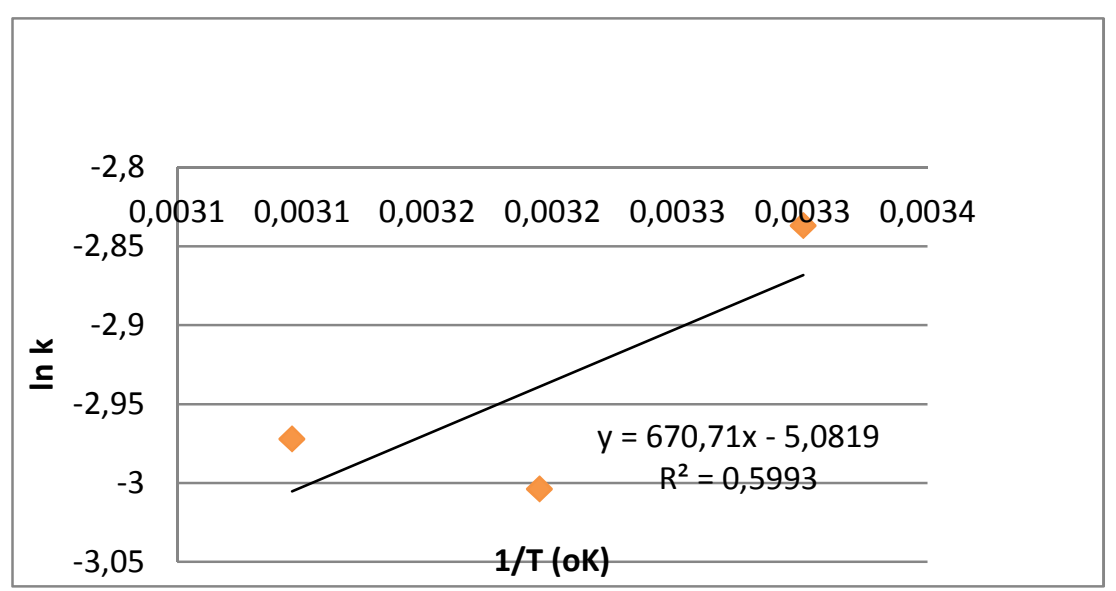

Gambar 6. Grafik Persamaan Arrhenius ln k versus suhu $(1 / \mathrm{t})\left({ }^{0} \mathrm{~K}\right)$ parameter $\mathrm{pH}$

Nilai slope dari persamaan linier masing-masing suhu pada Gambar 5 digunakan untuk menentukan nilai $\mathrm{ln} \mathrm{k}$. Plot ln $\mathrm{k}$ versus $1 / \mathrm{T}$ akan dihasilkan persamaan Arrhenius

Dari gambar 6 didapatkan persamaan Arrheniusy $=670,71 \mathrm{x}-5,0819$ sehingga diperoleh $\mathrm{Ea}=1332,70 \mathrm{kal} / \mathrm{mol}$.

\section{Analisa total padatan terlarut}

Hasil analisis menunjukkan bahwa semakin lama penyimpanan maka nilai total padatan terlarut sirup keranji cenderung semakin menurun pada berbagai suhu. Menurut Muchtadi (2010) penurunan total padatan terlarut tersebut dapat diakibatkan karena adanya pengaruh enzim yang dapat berasal dari mikroba atau secara alami terdapat pada bahan pangan. Enzim ini memungkinkan terjadinya reaksi kimia dengan lebih cepat sehingga dapat mengakibatkan berbagai macam perubahan pada komposisi bahan pangan. Menurut penelitian Winata dan Susanto, (2014) penurunan total gula pada nira tebu selama penyimpanan dapat disebabkan oleh terjadinya inversi yaitunya enzim invertase ada produk yang memecah sukrosa menjadi gula invert. 
Tabel 6. Persamaan regresi linier parameter TPT ordo nol dan ordo satu

\begin{tabular}{ccclc}
\hline $\begin{array}{c}\text { Suhu T } \\
\left({ }^{\circ} \mathrm{C} /{ }^{\circ} \mathrm{K}\right)\end{array}$ & \multicolumn{1}{c}{ Ordo Nol } & \multicolumn{2}{c}{ Ordo Satu } \\
\cline { 1 - 5 } $30(303)$ & & Persamaan Linier & $\mathrm{R}^{2}$ & \multicolumn{2}{c}{ Persamaan Linier } & $\mathrm{R}^{2}$ \\
\cline { 3 - 5 } & $\mathrm{y}=-1,7429 \mathrm{x}+64,8$ & 0,8116 & $\begin{array}{l}\mathrm{y}=-0,0464 \mathrm{x}+ \\
4,2513\end{array}$ & 0,7437 \\
$40(313)$ & $\mathrm{y}=-0,68 \mathrm{x}+61$ & 0,9844 & $\begin{array}{l}\mathrm{y}=-0,0132 \mathrm{x}+ \\
4,1193\end{array}$ & 0,9716 \\
$50(323)$ & $\begin{array}{l}\mathrm{y}=-0,5541 \mathrm{x}+ \\
63,689\end{array}$ & 0,7521 & $\mathrm{y}=-0,01 \mathrm{x}+4,1595$ & 0,7587 \\
\hline
\end{tabular}

Pemilihan ordo reaksi pada parameter total padatan terlarut dapat dilihat pada Tabel 6. Dari Tabel 6 dapat diketahui bahwa koefisien korelasi ordo nol lebih besar daripada koefisien korelasi ordo satu $\left(\mathrm{R}^{2}\right.$ ordo nol $>\mathrm{R}^{2}$ ordo satu), maka laju penurunan total padatan terlarut sirup kranji mengikuti reaksi ordo nol.

Gambar 7 merupakan grafik persamaan linier parameter total padatan terlarut versus lama penyimpanan pada berbagai suhu. Dari grafik diketahui penurunan total padatan terlarut semakin meningkat pada suhu optimum pertumbuhan mikroba. Penurunan total padatan terlarut selama penyimpanan juga dapat dikarenakan aktivitas mikroorganisme seperti kapang. Gula merupakan bagian dari total padatan terlarut yang digunakan sebagai sumber nutrisi bagi pertumbuhan kapang, sehingga semakin lama penyimpanan total padatan terlarut semakin berkurang.

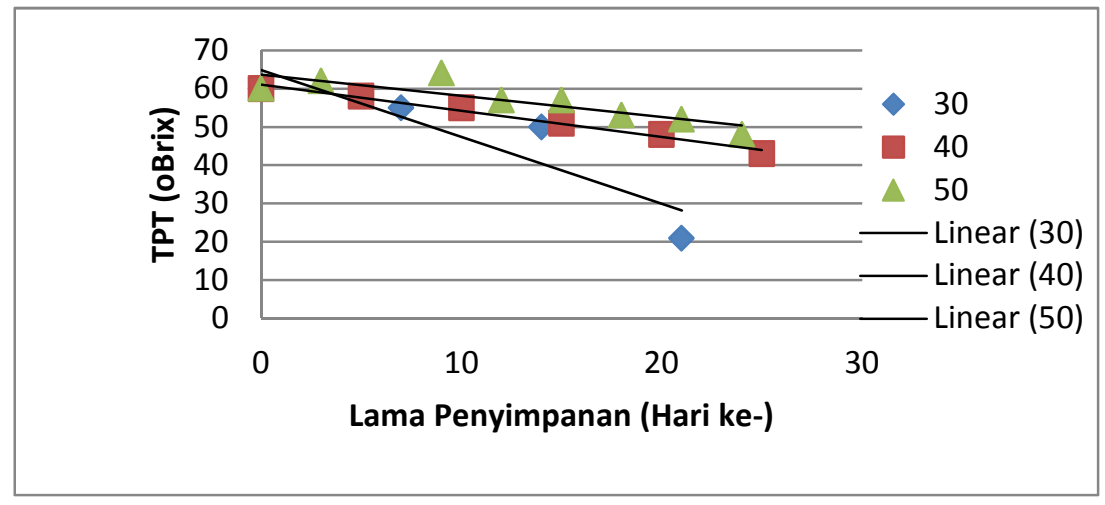

Gambar 7.Grafik TPT sirup kranji selama penyimpanan pada berbagai suhu

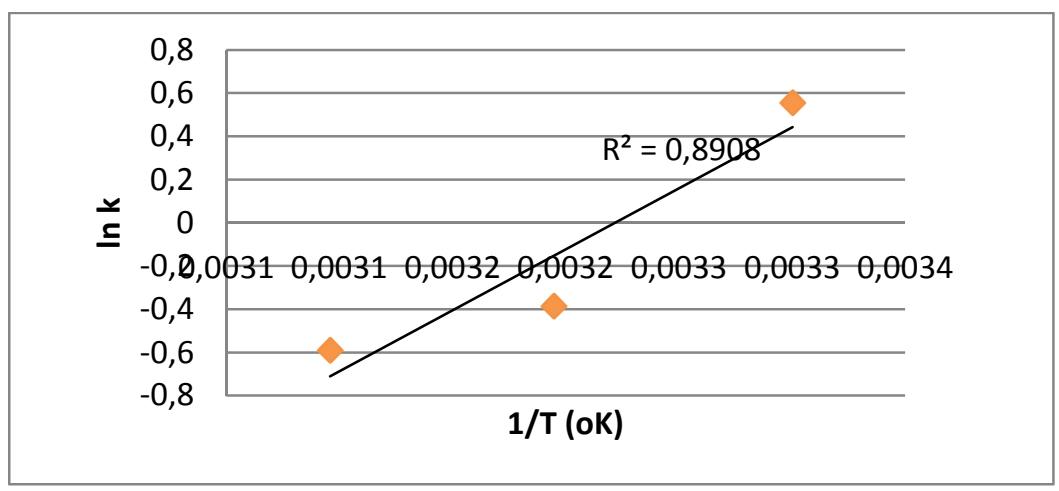

Gambar 8.Grafik Persamaan Arrhenius lnk versus suhu $(1 / \mathrm{t})\left({ }^{0} \mathrm{~K}\right)$ parameter $\mathrm{pH}$ 
Dari grafik dapat diketahui persamaan linier masing-masing suhu. Grafik $\ln k$ versus $1 / \mathrm{T}$ akan menghasilkan persamaan Arrhenius seperti Gambar 8.

Dari gambar 8 didapatkan persamaan y $=-5644,2 x+18,185$ dari persamaan tersebut dapat dihitung nilai energi aktivasi (Ea). Energi aktivasi didapatkan dari $\mathrm{R}$ nilai konstanta $(1,987)$ dikalikan dengan nilai slope $=b$ yaitu 5644,2, sehingga diperoleh $\mathrm{Ea}=11215,03 \mathrm{kal} / \mathrm{mol}$.

\section{Pendugaan Umur Simpan}

Pendugaan umur simpan dapat ditentukan berdasarkan parameter yang memiliki energi aktivasi terkecil.Interprestasi Ea (energi aktivasi) dapat memberikan gambaran mengenai besarnya pengaruh suhu terhadap reaksi (Laidler, 1950; Houston, 2001).

Nilai Ea juga menginterpretasikan energi minimum yang dibutuhkan oleh suatu reaksi (Benson, 1952). Nilai Ea yang besar menunjukkan energi interaksi antar molekul kuat (Bell and Labuza, 2000), sehingga untuk memulai suatu reaksi membutuhkan energi yang besar. Nilai Ea diperolah dari slope grafik garis lurus hubungan ln $\mathrm{k}$ versus (1/T). Nilai Ea akan mempengaruhi nilai $\mathrm{k}$ atau laju reaksi, nilai Ea yang kecil menunjukkan nilai $\mathrm{k}$ yang besar (Anonymous, 2008).

Dari Tabel 7 diketahui nilai energi aktivasi terkecil pada sirup keranji yaitu parameter total kapang, sehingga pendugaan umur simpan dapat ditentukan berdasarkan parameter total kapang.Menurut standar SNI No 01-3544-1994 tentang sirup batas pertumbuhan kapang maksimum adalah 50 koloni. Berdasarkan hasil analisa total kapang sirup kranji pada penyimpanan suhu $30^{\circ} \mathrm{C}$ pertumbuhan kapang $>50$ koloni pada penyimpanan hari ke 21 , sedangkan pada suhu $40^{\circ} \mathrm{C}$ pada hari ke 25 total kapang masih dibatas standar SNI yaitu 48 koloni, sehingga dapat diduga umur simpan sirup kranji adalah \pm 20 hari.

Berdasarkan uji organoleptik, pada minggu ketiga penyimpanan pada berbagai suhu sirup kranji masih disukai oleh konsumen dengan skor penerimaan $61 \%$ (suhu $30{ }^{\circ} \mathrm{C}$ ), 58,89\% (suhu $40{ }^{\circ} \mathrm{C}$ ), dan $55,56 \%$ (suhu $50^{\circ} \mathrm{C}$ ), sehingga dapat diketahui bahwa sirup kranji masih bisa diterima oleh konsumen jika diduga umur simpan sirup adalah \pm 20 hari.

Tabel 3. Umur simpan sirup kranji berdasarkan parameter perubahan mutu selama penyimpanan suhu $30^{\circ} \mathrm{C}\left(303^{\circ} \mathrm{K}\right)$

\begin{tabular}{|c|c|c|c|c|c|c|}
\hline Parameter & $\begin{array}{l}\text { Persamaan } \\
\text { Arrhenius }\end{array}$ & $\mathrm{R}^{2}$ & $\begin{array}{c}\text { Energi } \\
\text { Aktivasi } \\
(\mathrm{kal} / \mathrm{mol})\end{array}$ & Ln k & $\mathrm{k}$ & $\begin{array}{c}\text { Umur Simpan } \\
\text { (hari) }\end{array}$ \\
\hline Vitamin C & $\begin{array}{l}y=-4134,5 x+ \\
10,295\end{array}$ & 0,9483 & 8215,20 & $-3,3502$ & 0,0350 & 76,97 \\
\hline $\mathrm{pH}$ & $\begin{array}{l}y=670,71 x- \\
5,0819\end{array}$ & 0,5993 & 1332,70 & $-2,8683$ & 0,0568 & 22,36 \\
\hline $\begin{array}{l}\text { Total } \\
\text { Padatan } \\
\text { Terlarut }\end{array}$ & $\begin{array}{l}y=-5644,2 x+ \\
18,185\end{array}$ & 0,8908 & 11215,03 & 0,4427 & 1,5570 & 38,54 \\
\hline $\begin{array}{l}\text { Total } \\
\text { Kapang }\end{array}$ & $\begin{array}{l}y=269,85 x- \\
2,9814\end{array}$ & 0,0130 & 536,19 & $-2,0908$ & 0,1236 & 20 \\
\hline
\end{tabular}




\section{KESIMPULAN DAN SARAN}

\section{Kesimpulan}

1. Berdasarkan hasil penelitian didapatkan persamaan Arrhenius parameter total kapang y $=269,85 \mathrm{x}-2,9814$ dengan nilai energi aktivasi terkecil 536,19 $\mathrm{kal} / \mathrm{mol}$, sehingga pendugaan umur simpan ditentukan berdasarkan parameter total kapang. Umur simpan sirup kranji diduga \pm 20 hari pada penyimpanan suhu $30^{\circ} \mathrm{C}$.

2. Skor penerimaan konsumen terhadap sirup kranji pada minggu ketiga penyimpanan suhu $30^{\circ} \mathrm{C}$ yaitu $61 \%$.

\section{Saran}

Diharapkan dapat dilakukan penelitian lebih lanjut untuk pendugaan umur simpan sirup kranji dengan menggunakan metode analisa yang berbeda seperti metode akselerasi RH.

\section{DAFTAR PUSTAKA}

Anonymous, 2008. Course chapters: kinetics. developed by shodor incoorperation department of chemistry. The University of North Carolina at Chapel Hill. WebMaster@shodor.org. Anonymous, 2010. Rate Equation. http://en.wikipedia.org/wiki/Rate Equation.

Anonim, 2013. Pengertian buah Keranji. Diakses dari http://blogspot.com.

Arpah, 2003.Penentuan Kadarluwarsa pangan. Buku 2: Penuntut Praktikum. Jurusan Teknologi Pangan dan Gizi, Fakultas Teknologi Pertanian, Institut Pertanian Bogor.

Bell and Labuza L. N., and Labuza T.P. 2000. Moisture sorption: practical aspects of isotherm measurement and use, 2nd ed. St. Paul, MN: American Association of Cereal Chemists.

Benson, S.W., 1952. Chemical calculation: an introduction to the use of matematics in chemistry. John Wiley and Sons, Inc., New York, London

Biojana, 2012. Kandungan Dialium Indum L. http: //www. Biojana.com. Diakses pada tanggal 6 September 2013.

Buckle, K.A, R.A. Edwars. G.H. Fleet dan Wooton. Ilmu pangan. Penerjemah Hari Purnomo dan Adiono.1985. Universitas Indonesia Press. Jakarta

Cardelli and Labuza, C., and Labuza, T.P. 2001. Application of weibull hazard analysis to the determination of the shelf life of roasted and ground cofee. Lebensm.-Wiss.u-Technol 34,:273-278

Fennema, O.R. 1996. Food chemistry. $3^{\text {rd }}$ ed. Marcel Dekker, Inc. New York. Basel. Hong Kong.

Hough, G., Garitta, L., Go'mez, G., 2006. Sensory shelf-life predictions by survival analysis accelerated storage models. Food Quality and Preference $17: 468-473$.

Houston, P.L., 2001. Chemical kinetics and reaction dynamis- $1^{\text {st }}$ ed. Mc Graw-Hill Inc., Cornel University.

Labuza,T.P., 1982. Shelf life dating of foods. Food and Nutrition Press, USA.

Laidler, 1950. Chemical kinetics. McGrawHill Book Company, Inc, New York, Toronto, London.

Martono, Y., Sari, P., E., Hidarto, J. 2014. Menggunakan Model Arrhenius untuk untuk pendugaan masa simpan produk minuman kemasan berdasarkan kandungan Vitamin C.

Muchtadi, T. R dan Sugiyono. 1992. Ilmu pengetahuan bahan pangan. IPB, Bogor

Mukaromah, U., Susetyorini, S.H., Aminah, S., 2010. Kadar Vitamin C, mutu fisik, $\mathrm{pH}$ dan mutu organoleptik sirup Rosella (Hibiscus Sabdariffa, L.) berdasarkan cara ekstraksi. Jurnal Pangan dan Gizi 1(1) 
SNI 7388, 2009. Batas maksimum cemaran mikroba dalam pangan. Badan Standarisasi Nasional.

SNI 01-3544, 1994. Sirup.Badan Standarisasi Nasional.

Supriadi, 1999. Rekayasa pangan. Universitas Gajah Mada, Yogyakarta.

Winarno, 1994. Kimia pangan dan gizi. Penerbit Universitas Gajah Mada Press. Yogyakarta.
Winata, E.D. dan Susanto, W.H. 2014. pengaruh penambahan antiinversi dan suhu imbibisi terhadap tingkat kesegaran nira tebu. Jurusan Teknologi Pertanian, FTP. Universitas Brawijaya. Malang. 